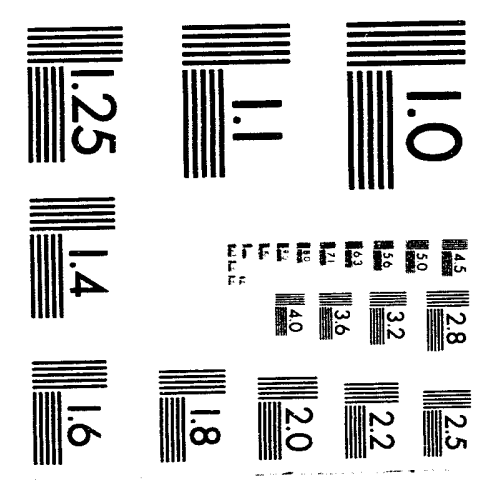



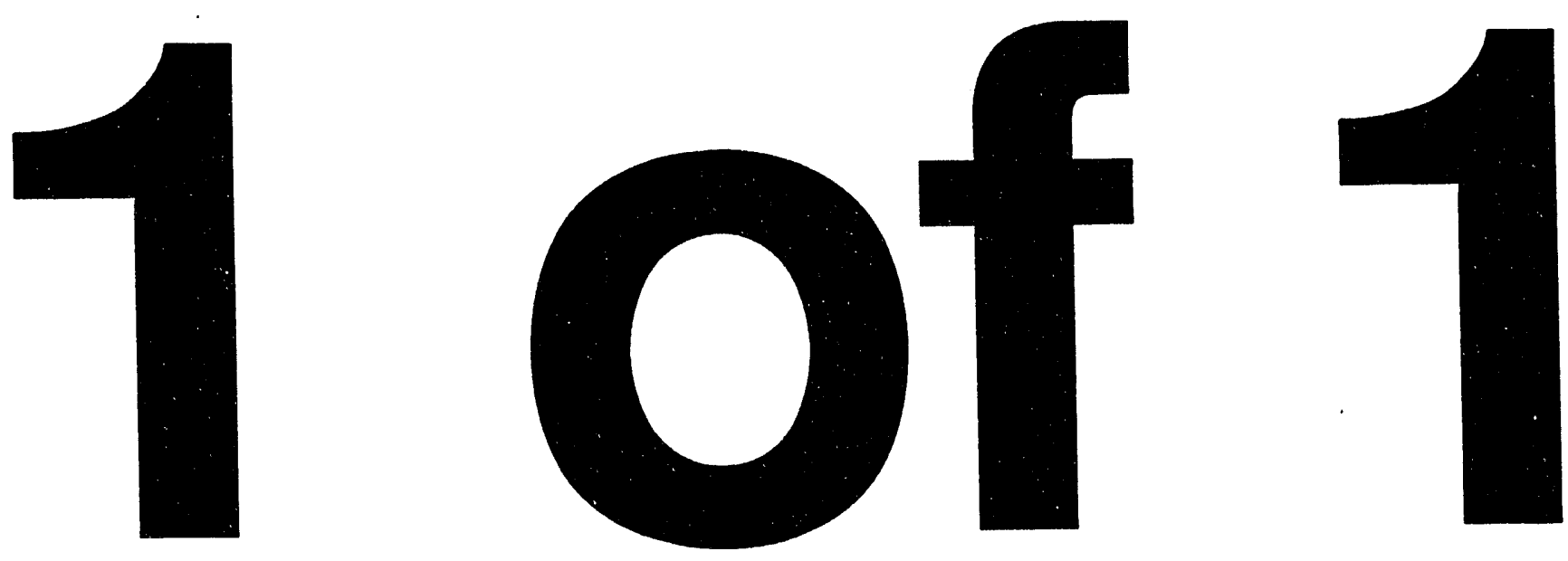


\section{COMPENDIUM OF BASINS FOR THE POTENTIAL APPLICABILITY OF JACK W. MCINTYRE'S PATENTED TOOL}

By

P. Damian Reed

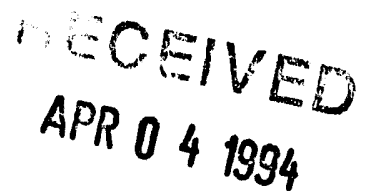

OSTI

March 1994

Work Performed Under Jack McIntyre/DOE Contract No. DE-FG46-92R699202

\section{DISCLAIMER}

For

Jack W. McIntyre

Fort Stockton, Texas

And

\section{U.S. Department of Energy}

Office of Scientific and Technical Information (OSTI)

Oak Ridge, Tennessee
This report was prepared as an account of work sponsored by an agency of the United States Government. Neither the United States Government nor any agency thereof, nor any of their employees, makes any warranty, express or implied, or assumes any legal liability or responsibility for the accuracy, completeness, or usefulness of any information, apparatus, product, or process disclosed, or represents that its use would not infringe privately owned rights. Reference herein to any specific commercial product, process, or service by trade name, trademark, manufacturer, or otherwise does not necessarily constitute or imply its endorsement, recommendation, or favoring by the United States Government or any agency thereof. The views and opinions of authors expressed herein do not necessarily state or reflect those of the United States Government or any agency thereof.

By

Geraghty \& Miller, Inc.

Midland, Texas

\section{MASTER}

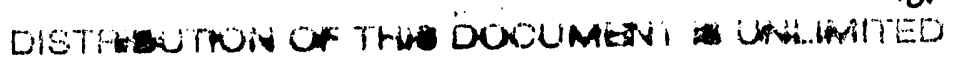




\section{CONTENTS}

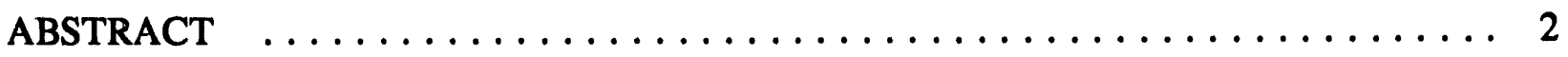

SAN JUAN BASIN $\ldots \ldots \ldots \ldots \ldots \ldots \ldots \ldots \ldots \ldots \ldots \ldots \ldots \ldots \ldots \ldots \ldots \ldots \ldots$

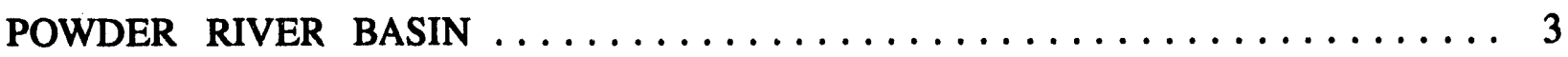

GREATER GREEN RIVER BASIN $\ldots \ldots \ldots \ldots \ldots \ldots \ldots \ldots \ldots \ldots \ldots$

PICEANCE BASIN $\ldots \ldots \ldots \ldots \ldots \ldots \ldots \ldots \ldots \ldots \ldots \ldots \ldots \ldots$

BLACK WARRIOR BASIN $\ldots \ldots \ldots \ldots \ldots \ldots \ldots \ldots \ldots \ldots \ldots \ldots$

APPALACHIAN BASIN $\ldots \ldots \ldots \ldots \ldots \ldots \ldots \ldots \ldots \ldots \ldots$

CENTRAL APPALACHIAN BASIN $\ldots \ldots \ldots \ldots \ldots \ldots \ldots \ldots \ldots, 9$

NORTHERN APPALACHIAN BASIN $\ldots \ldots \ldots \ldots \ldots \ldots \ldots \ldots \ldots 10$

MICHIGAN BASIN $\ldots \ldots \ldots \ldots \ldots \ldots \ldots \ldots \ldots \ldots \ldots \ldots \ldots \ldots \ldots \ldots \ldots$

JACK W. McINTYRE'S PATENTED TOOL $\ldots \ldots \ldots \ldots \ldots \ldots \ldots \ldots \ldots, 12$ 


\title{
COMPENDIUM OF BASINS FOR THE POTENTIAL APPLICABILITY \\ OF JACK W. MCINTYRE'S PATENTED TOOL
}

\begin{abstract}
Geraghty \& Miller, Inc. of Midland, Texas conducted geological and hydrological feasibility studies of the potential applicability of Jack W. McIntyre's patented tool for the recovery of natural gas from coalbed formations in the San Juan, Powder River, Greater Green River, Piceance, Black Warrior, Appalachian and Michigan basins. Results from the surveys indicated that geology dominated research efforts for many of the basins. Limited information exists on the hydrology and water quality of the basins. All of the basins contain some potential for the use of Jack McIntyre's patented tool.
\end{abstract}

\section{SAN JUAN BASIN}

The San Juan Basin is dominated by a geosyncline in the central portion of the basin into which detritus material from surrounding mountains and ridges was deposited. Tilting, subsidence and uplift caused periodic transgressive and regressive cycles which produced a variety of both marine and non-marine depositional environments. Pressures, temperatures and time acted on these depositional sequences to produce coal and coalbed methane. The basin is the most active in the western United States from the standpoint of coalbed methane development. 
Groundwater is known to occur in many of the coalbed producing formations of the basin. Existing produced water is disposed of in formations found below the Fruitland and Pictured Cliffs in the Cliff House, Menefee and Point Lookout (Mesaverde Group). Additional deeper formations used for produced water disposal are the Morrison, Bluff, and Entrada sandstones.

The quality of the water from aquifers in the basin appears to be best in the upper formations and decreases in quality with depth. However, some fresh water aquifers are known to occur at depths where typically brackish and brine waters are found. There is a direct relationship between the rate at which groundwater can be produced from these formations and the thickness of the aquifer, porosity, permeability, grain size, presence or lack of fractures and hydraulic continuity.

Historically, surface waters of the San Juan Basin area have been the primary source of water for public supply. These surface waters have now been appropriated by the state, and additional groundwater resources exploration are planned. Coalbed methane gas completion information for some areas of the San Juan Basin show a high production of poor quality water. This makes the basin a potential candidate for Jack McIntyre's patented tool. 


\section{POWDER RIVER BASIN}

The Powder River Basin is a broad, asymmetrical feature formed as a result of the uplift of surrounding structural elements during the Laramide orogeny. The development of the Black Hills uplift and the Bighorn Mountains provided a source of clastic sediments which eventually filled the present basin area and provided a substrate for heavy vegetative growth in a broad deltaic environment. The accumulation of vegetative matter in the early basin culminated in the development of the most extensive coal deposits found in the United States.

The coals of the Powder River Basin are considered thermally immature and are generally graded as subbituminous $\mathrm{C}$ or less. While these deposits do not contain the high methane concentrations associated with more mature coals in other basins, the abundance of numerous and often thick coal seams in the Powder River Basin offer substantial potential for the accumulation and possible development of large total volumes of coalbed methane.

Water is a recognized obstacle in the development of this potential resource; however, the application of Jack W. McIntyre's patented production process may be found to be most appropriate in the Powder River Basin. The process is designed specifically to separate produced water and produced gas in a downhole environment and may allow for more efficient and economical development of coalbed methane resources in this area. 
Through the application of a two-phased production approach, with initial production in the relatively water-free sandstones adjacent to the numerous coalbeds and secondary production from coals where water is much more abundant, it may be possible to maximize production potentials with a minimum of expense to the operator and with very limited environmental impact, when compared to surface disposal or deep underground injection disposal methods.

The compatibility of water produced from the coalbeds with waters found within the adjacent sandstone horizons should not be a problem as sodium sulfate is the predominant water type throughout the coal-bearing Fort Union Formation. Water from the overlying Wasatch Formation can be expected to exhibit a much greater variability in chemical quality which may be considered incompatible with water in deeper horizons and may preclude their viability as receptors for disposal purposes.

\section{GREATER GREEN RIVER BASIN}

The Greater Green River Basin is geologically similar to the San Juan Basin. The basin is a broad synclinal basin into which detritus material from surrounding uplifts and mountains were deposited. In addition, the basin includes the more geologically complex Hams Fork Coal Region which is within the Wyoming Thrust Belt located on the western side of the Greater Green River Basin. Folding, subsidence and uplift caused periodic transgression and regression cycles which produced a variety of both marine and non-marine 
depositional environments. Pressure, temperature and time acted on these depositional sequences to produce coal and coalbed methane. The basin has significant reserves of gas in place estimated by the Department of Energy (DOE) at between 1 and 30 trillion cubic feet (Tcf) of coalbed methane. Development of this resource is limited by unpredictable reserves and often low rates of gas production. Associated sandstone production often finds limited reservoirs or water producing sands laterally to gas productive sands. Enhanced stimulation and production technology will need to be applied in order to bring about the successful development of these resources.

Production will be enhanced in areas of natural fracturing. These fractures will most likely be structurally induced both in anticlinal and synclinal situations. The synclinal areas will possibly contain greater amounts of water that those found on the anticlines.

Groundwater is known to occur in many of the coalbed methane producing formations of the Greater Green River Basin. The basin is considered a good basin for the use of Jack W. McIntyre's patented tool due to the large amounts of poor quality water being produced form the coalbed methane wells in the area.

Low rank coal with modest gas content and fresh water are encountered within the Green River subordinate basin. However, medium volatile bituminous coals containing 400 Tcf/ton of methane gas with associated saline water is known to exist in the steeply dipping flanks of the Rock Springs Uplift. In general, the water quality from the aquifers in the 
basin appears to be best in the upper formations and decreases in quality with depth. However, some fresh water aquifers are known to occur at depths where typical brackish and brine waters were expected. There is a direct relationship between the rate at which groundwater can be produced from these formations and the thickness of the aquifer, porosity, permeability, grain size, presence or lack of fractures and hydraulic continuity.

Gas well completion information on some areas of the Greater Green River Basin shows high water production of primarily poor quality. This makes the basin a potential candidate for Jack McIntyre's patented tool.

\section{PICEANCE BASIN}

The Piceance Basin has a significant potential for the production of coalbed methane and is one of the prime target coalbed methane areas in the western United States. As with the San Juan basin and Greater Green River basins, the Piceance Basin is dominated by a geosyncline in the central portion of the basin into which detritus material from surrounding mountains and ridges was deposited. Tilting, subsidence and uplift caused periodic transgressive and regressive cycles which produced a variety of both marine and non-marine depositional environments. Pressures, temperatures and time acted on these depositional sequences to produce coal and coalbed methane. The basin has significant reserves of gas in place estimated to be as much as $84 \mathrm{Tcf}$. Development of this resource is limited by unpredictable reserves and often low rates of gas production per well. Associated sandstone 
production often finds limited reservoirs or water producing sands laterally to gas productive sands. Enhanced stimulation and production technology will need to be applied to bring about the successful development of these resources.

Most of the completed wells in the Piceance Basin produce methane and wastewater (brine). The produced water is usually treated and released to a surface body of water in conformance with an NPDES permit. As with the San Juan and the Greater Green River basins, groundwater in the Piceance Basin ranges in quality from fresh to brine. Fresh water is known to occur primarily in the upper alluvium and shallow Tertiary rocks and near the outcrop of any of the deeper aquifers. Most communities in the Piceance Basin rely on surface water sources for their domestic water supply. However, groundwater is commonly used for irrigation. The source of most of the groundwater is either the Unita/Green River aquifer above the Mahogany Zone or the Parachute member of the Green River Formation below the Mahogany zone.

Gas well completion information on some areas of the Piceance Basin shows high water production of primarily poor quality. This makes the basin a potential candidate for Jack McIntyre's patented tool.

\section{BLACK WARRIOR BASIN}

The Black Warrior Basin is located in northeastern Mississippi and northwestern 
Alabama. The basin is roughly triangular in shape and is filled primarily with sediments of Mississippian and Pennsylvanian ages. The triangular shape is formed by the Paleozoic rocks that create the basin's boundary. The basin is largely covered by Cretaceous and younger sediments of the Gulf Coast Plain and Mississippi Embayment, but it is believed to be continuous in the subsurface with the Arkoma Basin of Arkansas and Oklahoma to the west. The uppermost strata of the basin are predominantly coal-bearing Pottsville Pennsylvanian-age formation sedimentary rocks. Pottsville strata are unconformably overlain by sediments no older than Late-Cretaceous.

The Black Warrior Basin is one of the principal coalbed methane basins in the continental United States. Coalbed gas drilling in the basin has resulted in average production ranging from 20 MCFD in 1980 to over 235 MMCFD in 1992.

Primarily, water which is being produced as a result of coalbed methane production is being disposed of by land treatment or treated and released to the surface waters. This makes the use of Jack McIntyre's patented tool a less viable option in the Black Warrior Basin. However, as Federal, state and local regulations become more stringent on wastewater treatment and disposal, Jack McIntyre's tool will become more applicable for coalbed methane production in the basin. 


\section{APPALACHIAN BASIN}

\section{CENTRAL APPALACHIAN BASIN}

The exploitation of coalbed methane in the Central Appalachian Basin was begun during the 1930's. Information derived from published sources suggests that the potential for additional activity, on a commercially viable basis, is real. Published estimates of methane gas reserves indicate a total of approximately 5 trillion cubic feet may be found in this area. Documentation of established gas production in the Central Basin indicates that water production is less than 50 barrels of water per day for the average well.

The review of coal-bearing strata information indicates that sandstone formations are often found in close proximity to many of the individual coalseams. These sands are often very immature in lithological character and are, in many cases, productive fresh water aquifers in the Central Basin area. With the possible exception of the Lee Formation in southwestern Virginia, none of these sand bodies are massively bedded with wide lateral extent beyond their outcrop. The potential for down-hole disposal of produced fluids should be evaluated in consideration of these factors. The value of each sandstone as either a producing or potential fresh water source should be evaluated.

The extensive production of coal in this area has had an impact on the availability of commercial reserves of coalbed methane through loss to the atmosphere. In addition, 
the acquisition of property by commercial coal operations, either through lease or purchase, will limit the exploration activities of the methane gas producer. This issue is further complicated by the as yet unresolved matter of resource ownership.

Some potential does exist in the Central Appalachian Basin for the application of Jack W. McIntyre's patented production process.

\section{NORTHERN APPALACHIAN BASIN}

The Northern Appalachian Basin is a relatively un-deformed spoon-shaped basin. A series of northwest-southwest trending anticlines and synclines exist within the basin. The basin is located within Pennsylvania, Maryland, West Virginia, Ohio and Kentucky. The area extent of the basin is approximately 43,000 square miles.

Coal within the basin is of both Pennsylvanian and Permian age. Coal seams average 1 to 3 feet thick with the thickest coal seams occurring in the Pittsburgh Formation (approaching 12 feet thick in places). The major coal seams are in the Allegheny and Monongahela groups. Coal depths range from outcrops to 2,000 feet below ground surface. Coal rank is high volatile bituminous to low volatile bituminous and coal resources are estimated at 353 billion tons.

Coalbed methane resources are estimated at $61 \mathrm{Tcf}$ of gas in-place. The potential 
economics of producing coalbed methane from the basin is considered high. However, legal issues (i.e. ownership rights) has limited the development of the Northern Appalachian Basin from the standpoint of coalbed methane gas production. Further issues such as disposal problems associated with production water has further limited the production of coalbed methane gas from the basin. Given the limited information reviewed on groundwater hydrology of the basin, the potential applicability for the use of Jack McIntyre's patented tool was not evaluated.

\section{MICHIGAN BASIN}

The Michigan Basin is an interior cratonic basin with a Paleozoic sedimentary section up to 16,000 feet in total thickness. Quaternary glacial drift deposits extend across most of the basin and overlie Jurassic and Paleozoic formations.

Pennsylvanian coal seams of the Saginaw Formation are generally at shallow depths $(<100$ feet), laterally discontinuous and were not reported to be a potential major resource for coalbed methane gas. Oil and gas is produced from Mississippian-and Ordovician-age formations. The majority of the fields produce oil and gas along with water and were not considered for this report. A more localized study of individual wells which produce gas and significant quantities of water may reveal potential application of Jack McIntyre's gas recovery/water disposal process. 
The Devonian Antrim Shale is a major natural gas reservoir which produces significant quantities of gas and water. To date, over 2,700 wells have been completed in the Antrim Shale. Antrim Shale gas/water annual production for 1992 totaled 74,209,916 Mcf/25,795,334 bbl, respectively, from 2,626 on-line wells in 156 fields. The Middle Devonian Dundee Limestone is a major injection zone for produced waters which is used for disposal of produced waters from the Antrim Shale. "Waterless" completion wells are producing Antrim Shale gas and simultaneously disposing of water into the Dundee Limestone.

Jack W. McIntyre's patented process for gas recovery and water disposal has potential application for dewatering of the Antrim Shale into the Dundee Limestone in the Michigan Basin. "Waterless" completion wells are currently in use in the Antrim Shale gas reservoir and the Dundee Limestone injection zone.

\section{JACK W. MCINTYRE'S PATENTED TOOL}

Current technology for dewatering gas wells involves pumping water to the surface, separating dissolved gases, treating, and re-injecting the water into a disposal well. Jack W. McIntyre's patented tool solves the problem of raising and re-injecting the produced water. In simplified terms, the wellbore adjacent to the production formation is under-reamed to form a collection chamber. Gravity separates hydrocarbons from the liquids, which drain into the under-reamed collection chamber. The gases, being lighter, move upward through 
the casing while the liquids flow down by gravity.

In conventional natural gas resources, much higher flow rates and the ultimate recovery of the resource are increased with this new completion technology. This is accomplished by the following means:

- Water buildup around the wellbore is kept to a minimum.

- When bottom water is present, lower perforations pick up water from the coning effect. This allows upper perforations to produce mostly gas and serves to control the gas/water interface.

- The method lowers the water saturation cut-off value, allowing long intervals of heterogeneous layers in the well to be produced, while simultaneous disposal of the water is occurring downhole.

- Water channelled into the wellbore by acid jobs, bad cement jobs, or hydraulic fracturing into free-water zones moves downhole as soon as it enters the wellbore. Gas production continues even if these problems cause high water into the well.

- Bottom hole flowing pressure is totally controllable and can be lowered to any pressure desired above the pipeline pressure. The recovery factor of the gas in-place is therefore increased.

- Gas flows in single phase from the producing formation to the surface, eliminating the pressure drop that water flow creates. 
This invention is beneficial to environmental safety because it eliminates volumes of potentially hazardous waste-water, which is normally produced with conventional completion technology. It also generates a second source of energy savings, whether in rejuvenating water-logged wells or in producing new wells, by eliminating the need for separately drilled disposal wells. 

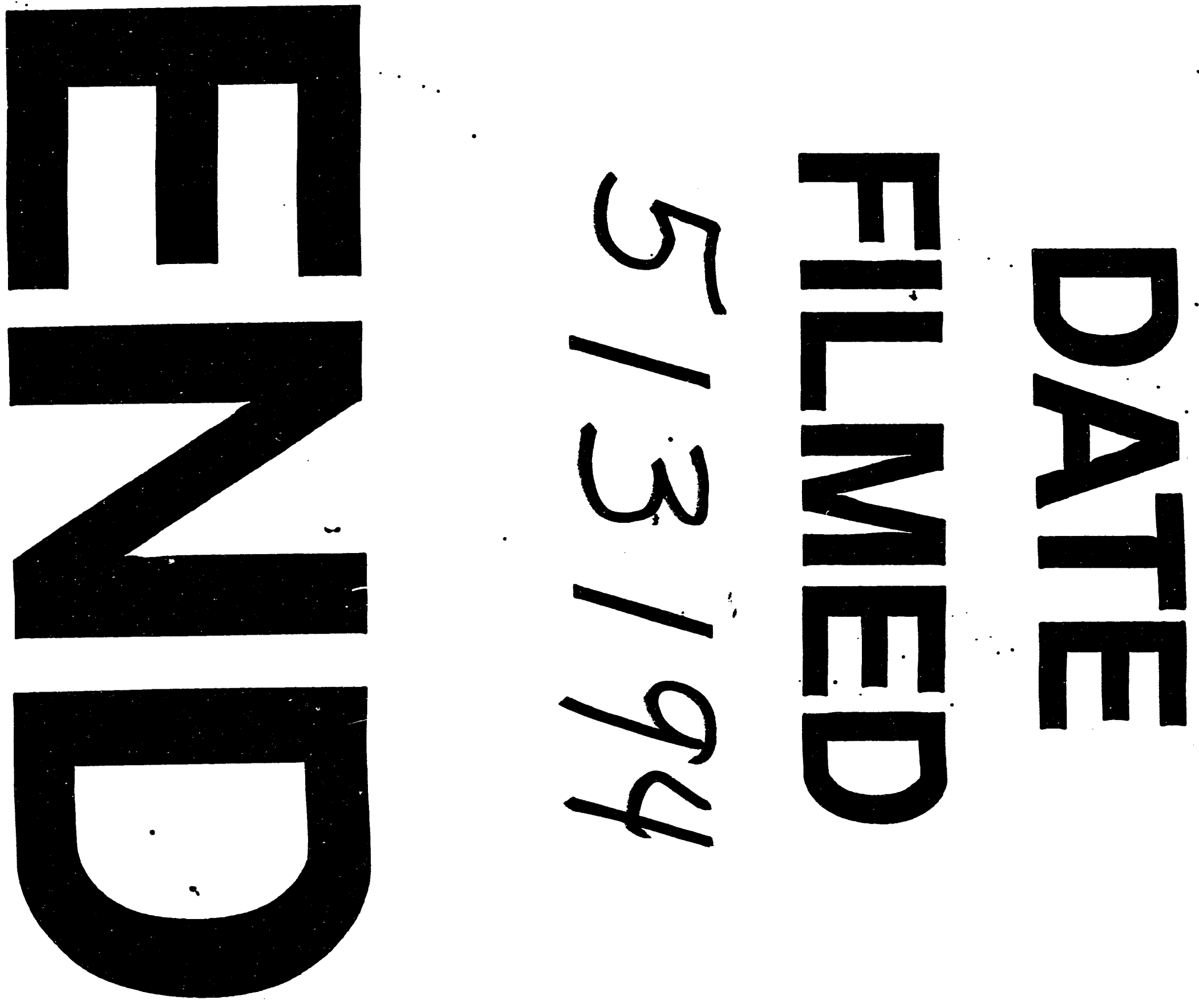


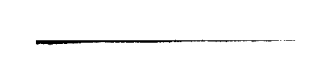

